\title{
Mineralogical and chemical characteristics of Bajocian-Bathonian shales, G. Al-Maghara, North Sinai, Egypt: Climatic and environmental significance
}

\author{
Ibrahim M. Ghandour, * Harue Masuda and Wataru Maejima \\ Department of Geosciences, Osaka City University, Sumiyoshi-ku, Osaka 558-8585, Japan
}

(Received April 19, 2002; Accepted August 23, 2002)

\begin{abstract}
Clay mineral assemblages in relation to the chemical characteristics of Bajocian-Bathonian shales at G. Al-Maghara, North Sinai, Egypt, have been determined to infer the climatic conditions and the factors regulating their distribution. Mineralogical analyses using XRD revealed the dominance of kaolinite relative to illite and smectite. Quartz, calcite, goethite, feldspars and plagioclase represent the non-clay minerals encountered. Chemical data reflect the enrichment of chemically immobile elements ( $\mathrm{Al}, \mathrm{Ti}, \mathrm{Zr}$ and $\mathrm{Sc})$ and the depletion of mobile elements ( $\mathrm{Fe}, \mathrm{Ca}, \mathrm{Na}, \mathrm{K}$ and $\mathrm{Mg}$ ). Major element concentrations reflect the dominant mineralogical composition and the weathering history of the source area. Moreover, the enrichment of trace elements ( $\mathrm{Sc}, \mathrm{Zr}$ and partially $\mathrm{Cr}$ ) could be attributed to the source rock chemistry and its weathering history. High values of the Chemical Index of Alteration (CIA) $\left(\mathrm{Al}_{2} \mathrm{O}_{3} /\left(\mathrm{Al}_{2} \mathrm{O}_{3}+\mathrm{CaO}+\mathrm{K}_{2} \mathrm{O}+\right.\right.$ $\left.\mathrm{Na}_{2} \mathrm{O}\right) \times 100$ ) were found. The high proportion of kaolinite associated with the enrichments of immobile particularly major elements ( $\mathrm{Al}$ and $\mathrm{Ti}$ ) and the high values of CIA suggest intensive chemical weathering of the source rock under tropical to subtropical humid climatic conditions. The abundance of kaolinite relative to smectite was also influenced by hydraulic sorting and relative sea level changes.
\end{abstract}

\section{INTRODUCTION}

Climatic changes along with the eustatic sea level changes and the local and regional tectonics are the main controlling factors that drive sedimentation and influence depositional patterns (De Wet, 1998). Sedimentary successions bear several clues for paleoclimatic interpretations ranging from major lithologic composition (siliciclastics/carbonate content), fossils content (plants or fauna, calcareous or siliceous), and mineralogical and chemical characteristics. Among of these clues clay minerals and inorganic chemical composition of mudrocks have been used for a long time as paleoclimatic indicators (Hallam et al., 1991; Lindgreen and Surlyk, 2000; Nesbitt and Young, 1982; Young and Nesbitt, 1998 and others).
The present study aims at evaluating the climatic and depositional controls on the BajocianBathonian succession at G. Al-Maghara, Sinai, Egypt, using clay mineral and geochemical analyses of mudrocks. This succession is particularly well suited for such type of an investigation. This succession is developed in a half graben rift basin (Ayyad et al., 1998), which is uniquely positioned to record paleoclimatic fluctuations in its sedimentary successions (Johnson, 1996). Moreover, this succession is dominated by siliciclastic sediments with minor carbonate intercalations and showing rapid alternation of facies that would be a result of tectonic, climatic, and sea level changes.

The thick $(\sim 2000 \mathrm{~m})$ and complete Jurassic succession that crops out at G. Al-Maghara, N. Sinai, has attracted the attention of geologists since the discovery of coal deposits in the Safa

*Corresponding author (e-mail: Ghandour@sci.osaka-cu.ac.jp) 
Formation (Al-Far, 1966). Several published and unpublished papers and reports dealt with stratigraphy (e.g., Jenkins et al., 1982), invertebrate macro- and micro-paleontology (e.g., Hegab, 1991; Shahin, 2000 and others), structure and tectonics (e.g., Moustafa and Khalil, 1989 and others) and mining and coal geology (e.g., Nakhla, 1988). The most recently work dealt with the organic geochemistry of the coal rich Safa Formation was carried out by Mostafa and Younes (2001). Mineralogical studies are very limited (El-Anbaawy and Youssef, 1989; El-Sharkawi et al., 1989). Yet, none of these studies tried to determine the effect of climate and long-term depositional controls on the mineralogy and chemical composition of Bajocian-Bathonian shales.

\section{Geologic Setting}

G. Al-Maghara is located in North Sinai, some $70 \mathrm{~km}$ south of the Mediterranean Sea at longitudes $33^{\circ} 10^{\prime}$ and $33^{\circ} 35^{\prime} \mathrm{E}$ and latitudes $30^{\circ} 35^{\prime}$ and $30^{\circ} 50^{\prime}$ N. G. Al-Maghara is an asymmetric anticline bearing $\mathrm{N} 25^{\circ} \mathrm{E}$ to $\mathrm{N} 60^{\circ} \mathrm{E}$ dipping gently to the north and steeply to the southeast (Fig. 1). Stratigraphically, G. Al-Maghara is composed of thick ( 2000 m thick) Jurassic sediments, which are subdivided into six formations (Al-Far, 1966) arranged in ascending order as: Mashabbah, Rajabiyah and Shushah formations (Early Jurassic), Bir Maghara and Safa formations (Middle Jurassic) and Masajid Formation (Late Jurassic).

The tectonic evolution of N. Sinai was influ-

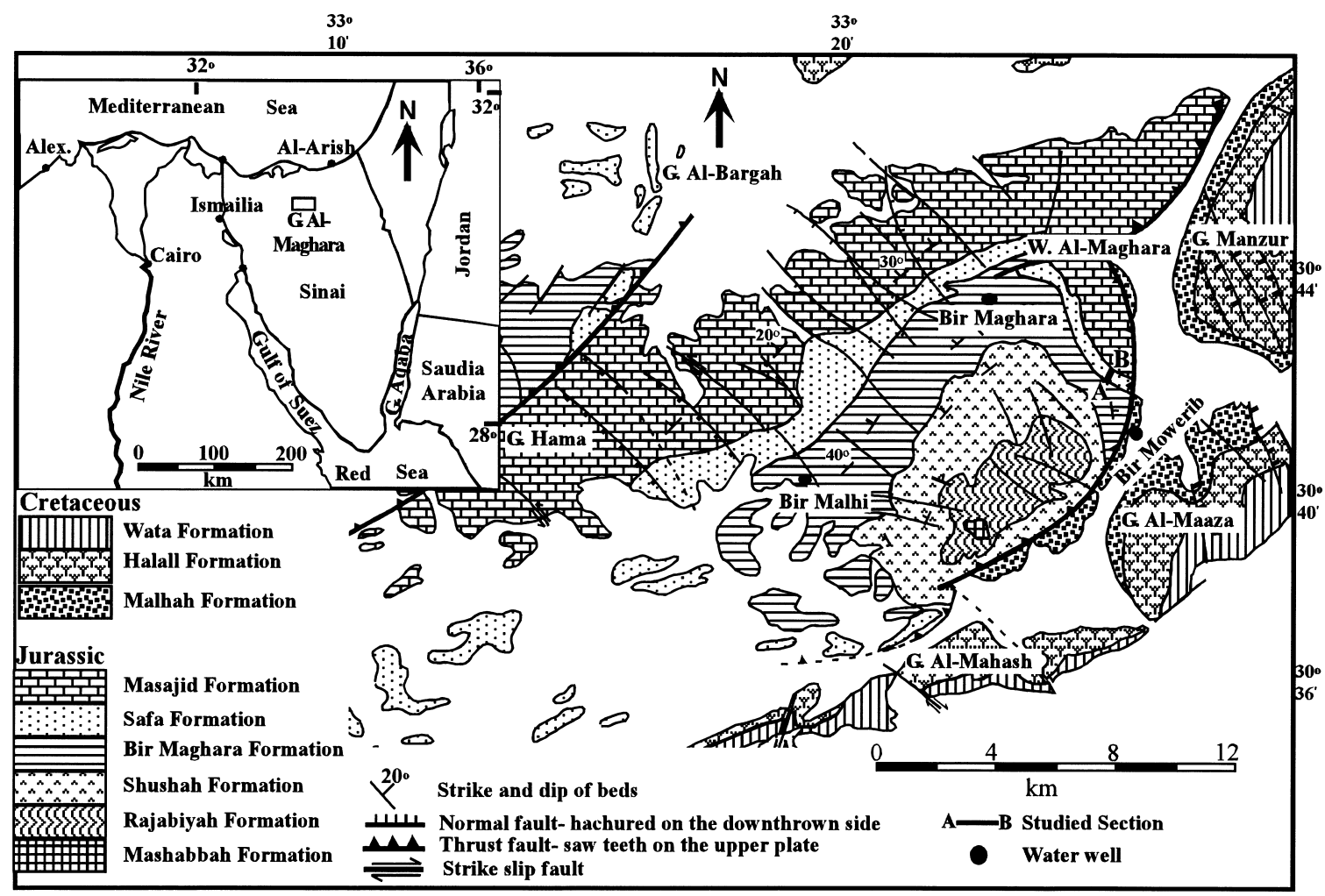

Fig. 1. Location and simplified geologic maps of G. Al-Maghara (modified after Egyptian Geologic Survey, 1993). 
enced by extensional stresses related to the opening and the evolution of the Tethyan Ocean, as well as the orientation and position of the PreCambrian basement fabrics and structures. Sev- eral recent syntheses of the tectonic setting of North Egypt as a whole and, especially, N. Sinai are available (Moustafa and Khalil, 1989; Ayyad et al., 1998; Guiraud et al., 2001). The sedimen-
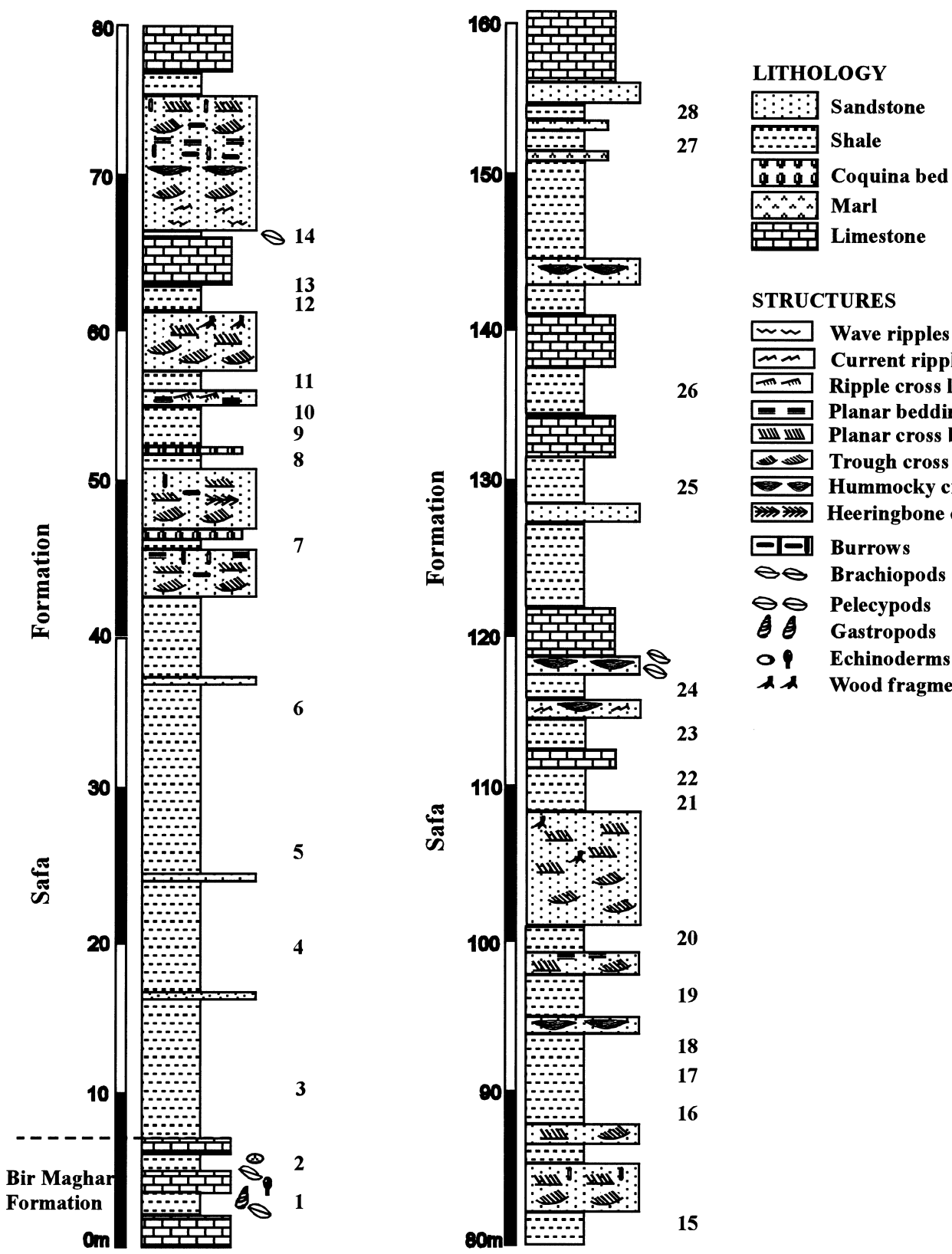

STRUCTURES

\begin{tabular}{|c|c|}
\hline in & Wave ripples \\
\hline mM & Current ripples \\
\hline$a n$ & Ripple cross lamination \\
\hline$E=$ & Planar bedding \\
\hline iाI IIII & Planar cross bedding \\
\hline$\Delta \infty$ & Trough cross bedding \\
\hline 02 & Hummocky cross bedding \\
\hline$m$ & Heeringbone cross bedding \\
\hline$\theta$ & Burrows \\
\hline$e$ & Brachiopods \\
\hline & Pelecypods \\
\hline & Gastropods \\
\hline & Echinoderms \\
\hline$\lambda \lambda$ & Wood fragments \\
\hline
\end{tabular}

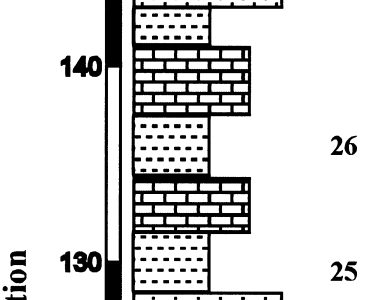

$\approx \sim$ Wave ripples

Mn Current ripples

Ripple cross lamination

Planar bedding

피 IIII) Planar cross bedding

Trough cross bedding

Hummocky cross bedding

Heeringbone cross bedding

$\theta-$ Burrows

$\theta \ominus$ Brachiopods

$\theta \theta$ Pelecypods

Gastropods

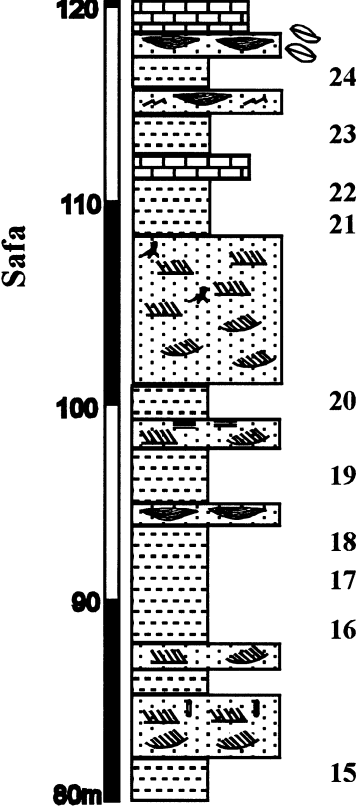

Fig. 2. Stratigraphic section through Bajocian-Bathonian at the Bir Mowerib location on the steeply dipping southeastern limb of Al-Maghara anticline. Samples used for mineralogical and geochemical analyses are indicated to the right of the column. 
tary successions in North Sinai were deposited in half graben sedimentary basins during the Early Mesozoic and were later inverted and folded during Early Cretaceous as a result of the Laramide compressive movements (Ayyad et al., 1998). Structural studies across North Sinai indicated syndepositional tectonism revealed by the abrupt thickening of Jurassic strata northward. For example, the Middle Jurassic succession attains thicknesses of $80 \mathrm{~m}$ at G. Al-Minsherah (Issawi et al., 1999), $444 \mathrm{~m}$ at G. Al-Maghara (Al-Far, 1966), and dramatically thickens northward to 780 $\mathrm{m}$ at Halal Well, $805 \mathrm{~m}$ at Giddi well and to 1800 $\mathrm{m}$ at Misri-1 Well (Ayyad et al., 1998).

Bajocian-Bathonian sediments, which are the target of this work, include the uppermost part of the Bir Maghara Formation and the Safa Formation (Fig. 2). The uppermost Bir Maghara Formation is composed of fossiliferous limestones and shales, suggesting deposition under normal marine conditions. One the other hand, the Safa Formation is economically important because it contains the main coal seams in Egypt and has been mined for a few decades. Lithologically, the Safa Formation is composed of 160-215 m of rippled and cross-bedded sandstones and shales interbedded with fossiliferous limestone and locally iron sulphides. The ratio of lime:mud:sand is 29:37:34 (Al-Far, 1966). Marine fauna and land plant fossils were recorded from the Safa Formation, suggesting Late Bajocian to Bathonian age (Al-Far, 1966; Hegab, 1991; Shahin, 2000). The Safa Formation sediments were deposited under marginal marine to shallow marine conditions. Lower Safa Formation had been deposits under progradational deltaic conditions whereas the upper part is deposited under transgressive linear shoreline settings (Maejima and Ghandour, 2002). The global eustatic sea level falls during the Middle Jurassic (Haq et al., 1988) are expressed at Al-Maghara area by two unconformities. The first is located at the Safa Formation/Bir Maghara Formation contact and the other separates Safa Formation into lower and upper parts (Maejima and Ghandour, 2002).

\section{AnAlytical TeChNiQues}

Twenty eight (28) shale samples collected from the steeply dipping south-eastern flank of AlMaghara anticline at Bir Mowerib (Fig. 1) were analysed in this study. The locations and the distance between samples are shown in Fig. 2. Most of the studied beds are poorly exposed and covered by thick (10-20 cm) debris. It was necessary in most samples to dig to get fresh samples. Most of the studied samples are friable and easy to disintegrate when soaked in water. All analyses were carried out at the Department of Geosciences, Osaka City University, Japan.

Small pieces $(50 \mathrm{~g})$ of shale samples were dried and gently powdered with agate mortar and pestle. For geochemical analysis the bulk rock is taken into consideration, whereas, mineralogical investigation were carried out on the coarse $(<45 \mu \mathrm{m})$ and the fine $(<2 \mu \mathrm{m})$ fractions. The $<45 \mu \mathrm{m}$ (coarse) fractions were separated using $45 \mu \mathrm{m}$ wet sieving. Samples were then packed into a cavitybearing glass slide (Hardy and Tucker, 1988). The slides were scanned by XRD at a scan speed of $1 \%$ minute from $2^{\circ}$ to $60^{\circ} 2 \theta$. For clay $(<2 \mu \mathrm{m})$ minerals analysis, $\mathrm{X}$-ray diffraction was undertaken on oriented aggregates. Samples were completely dispersed in diluted solution of calgon to avoid flocculation. The clay fractions $(<2 \mu \mathrm{m})$ were separated by centrifugation. Oriented samples of the clay $(<2 \mu \mathrm{m})$ fractions were prepared by carefully pipetting the clay suspension on a glass slide, allowing the fractions to be homogeneously distributed. For the determination of the clay mineral composition, the oriented samples were X-ray scanned under four separate conditions: air-dried, after saturation with ethylene glycol, after treatment with warm $6 \mathrm{~N} \mathrm{HCl}$ and after heating to $550^{\circ} \mathrm{C}$ (Hardy and Tucker, 1988). All slides were scanned at a scan speed of $1 \%$ minute at a range from $2^{\circ}$ to $40^{\circ} 2 \theta$. Minerals were identified by their characteristic reflections, as discussed by Moore and Reynolds (1989). The basic (001) reflection of glycolated smectite is $17 \AA$ and the (001) and (002) reflections of kaolinite are 7.16 $\AA$ and $3.58 \AA$, respectively. Illite was identified 
(A)

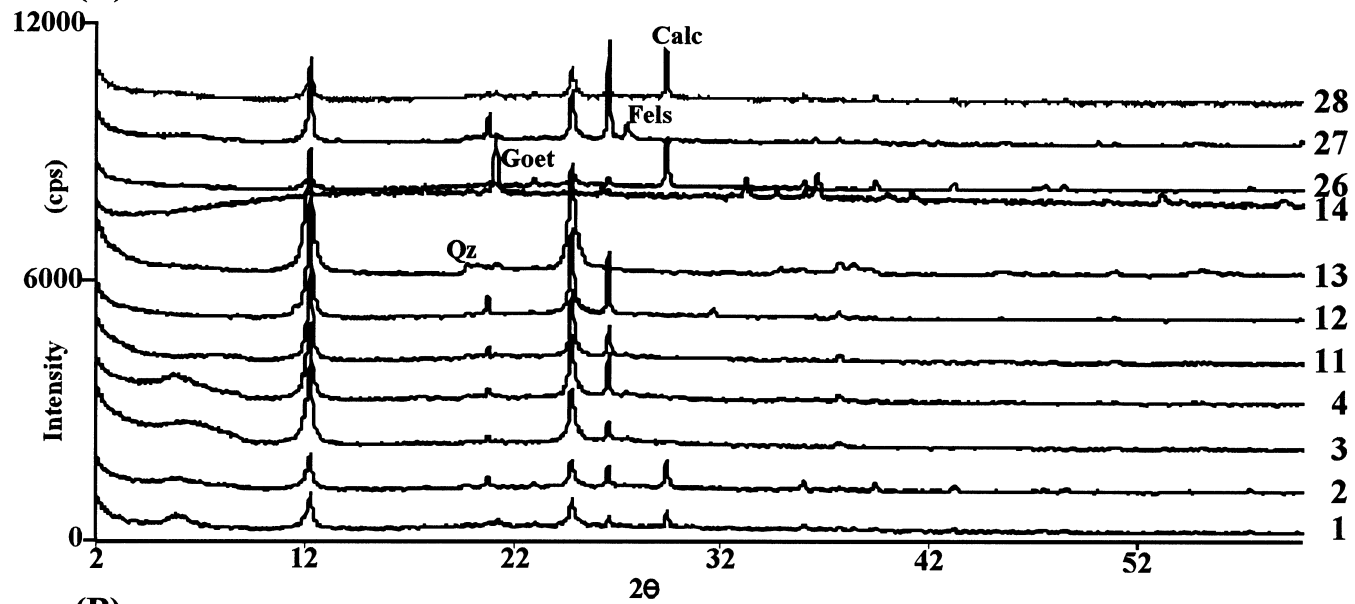

(B)
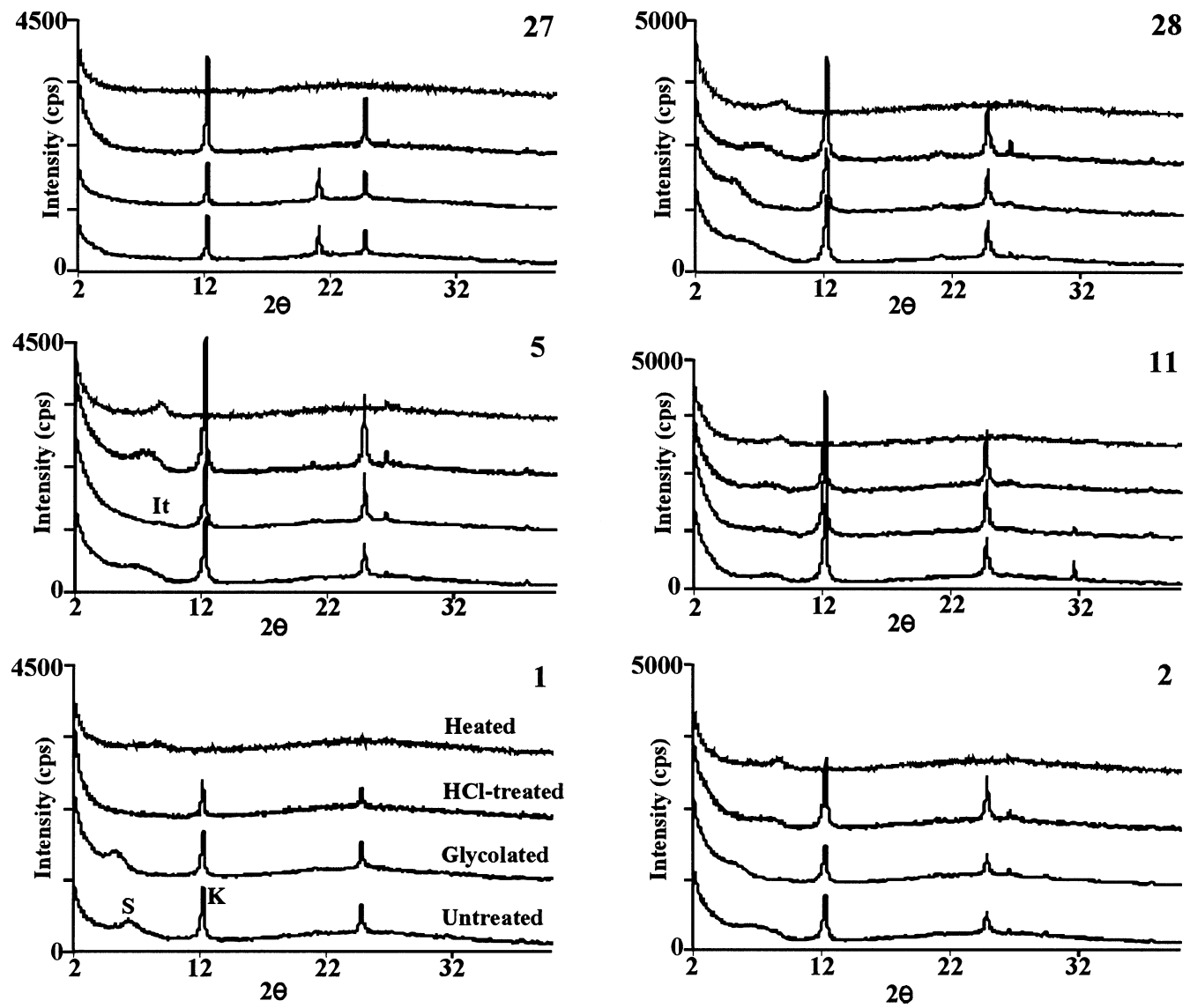

Fig. 3. Representative X-ray diffractograms of the Bajocian-Bathonian shales. (A) coarse fraction and (B) fine fraction. S: smectite, K: kaolinite, It: illite, Qz: Quartz, Calc: calcite, Goet: Goethite and Fels: K-Feldspars. Sample numbers are indicated in the upper right corner of the respective plots. 
using $10 \AA$ reflection. The following peaks identify non-clay minerals: quartz, $4.26 \AA$, goethite, $4.17 \AA$, plagioclase, $3.18 \AA$, K-feldspar, $3.25 \AA$ and calcite, $3.04 \AA$. All X-ray diffraction analyses were carried out using a RIGAKU RAD-I Xray Powdered Diffractometer with $\mathrm{CuK} \alpha$ radiation and energy of $30 \mathrm{kV}$ and current of $10 \mathrm{~mA}$. The detection limit for quartz and feldspars are $1 \%$, for calcite is $3 \%$ and for other minerals around $5 \%$. Because the intensity of the diffraction pattern (generally expressed as peak height or peak area) of a mineral in a mixture is proportional to its concentration, the relative proportions (semiquantitative in nature expressed as vol\%) of the identified minerals can be roughly determined using their peak intensities with the aid of MacDiff software (Petschik et al., 1996). In the case of coarse fraction, mineral abundances were determined using peak heights, whereas the integrated peak areas of glycolated samples were used to determine the relative abundances of the $<2 \mu \mathrm{m}$ fractions (Hardy and Tucker, 1988). Representative X-ray diffraction patterns of $<45 \mu \mathrm{m}$ and $<2$ $\mu \mathrm{m}$ fractions are illustrated in Figs. $3 \mathrm{a}$ and $3 \mathrm{~b}$, respectively. Freshly fractured fragments were gold coated and were observed using the JEOL JSM-5500 Scanning Electron Microscope (SEM).

The shales were analysed for major and trace element contents according to the following procedures. 200-300 mg of powdered samples was completely digested in Teflon beakers with a mixture of nitric, perchloric and hydrofluoric acids. The digested materials were then diluted by hydrochloric acid. The contents of $\mathrm{Na}$ and $\mathrm{K}$ were determined using SEIKO SAS-7500 Atomic Absorption Spectrophotometer (AAS), whereas the other major and trace elements were determined using SEIKO SPS-7700 Inductively Coupled Plasma Spectrophotometer (ICP-AES). The total iron is expressed as $\mathrm{FeO}^{*}$. The detection limits for the analyzed elements are mostly around 0.01 $\mathrm{ppm}$. The precision of the major and trace elements determined by two independent analyses is about $5-8 \%$ for all elements. The accuracy for most analyzed elements is in the range of $\pm 10 \%$. Loss on ignition (LOI) was not determined. The data obtained from the studied shales are compared with the average chemical composition of the Phanerozoic Shale (Condie, 1993), Upper Continental Crust (UCC) (Taylor and McLennan, 1985), Normal Pierre Shale (Schultz et al., 1980), North American Shale Composite (NASC) (Gromet et al., 1984), and Russian Mesozoic and Cenozoic Shales (RMCS) (Ronov and Migdisov, 1971). To test the role of chemical weathering in the formation of the studied shales, the Chemical Index of Alteration (CIA) was calculated using the method of Nesbitt and Young (1982). The index represents the molar ratios of $\left(\mathrm{Al}_{2} \mathrm{O}_{3} /\left(\mathrm{Al}_{2} \mathrm{O}_{3}+\mathrm{CaO}+\mathrm{K}_{2} \mathrm{O}+\right.\right.$ $\left.\mathrm{Na}_{2} \mathrm{O}\right) \times 100$. CIA values $<50$ indicate that the source rock is chemically unweathered, while those between 51 and 75 and $>75$ indicate moderate and strong weathering, respectively. The sediments that are enriched in non-silicate $\mathrm{CaO}$ (i.e., calcite-rich samples) are excluded from these calculations.

\section{RESUlts}

\section{Mineralogy}

The results of the mineralogical analyses are illustrated in Table 1 and Fig. 4. No obvious qualitative difference is found in the mineralogical composition of the coarse $(<45 \mu \mathrm{m})$ and the fine $(<2 \mu \mathrm{m})$ fractions. All the studied samples are mainly composed of clay minerals associated with quartz, calcite, goethite, with small amounts of Kfeldspar and plagioclase. The principal clay minerals are kaolinite, illite and smectite.

The relative proportions of the non-clay minerals are different in the two fractions. They are recorded in the coarse fraction, with higher relative concentrations than in the fine fraction. The quartz content varies from 4 to 20 vol\% (averaging 9 vol\%), and from $<1$ to 5 vol\% (averaging 3 vol\%) in the coarse and fine fractions, respectively. Both K-feldspars and plagioclase were found at low relative proportions if compared with other non-clay minerals. The average relative proportions of $\mathrm{K}$-feldspars are 3 and 2 vol\% in the coarse and fine fractions, respectively, whereas plagioclase occurs at an average relative concen- 

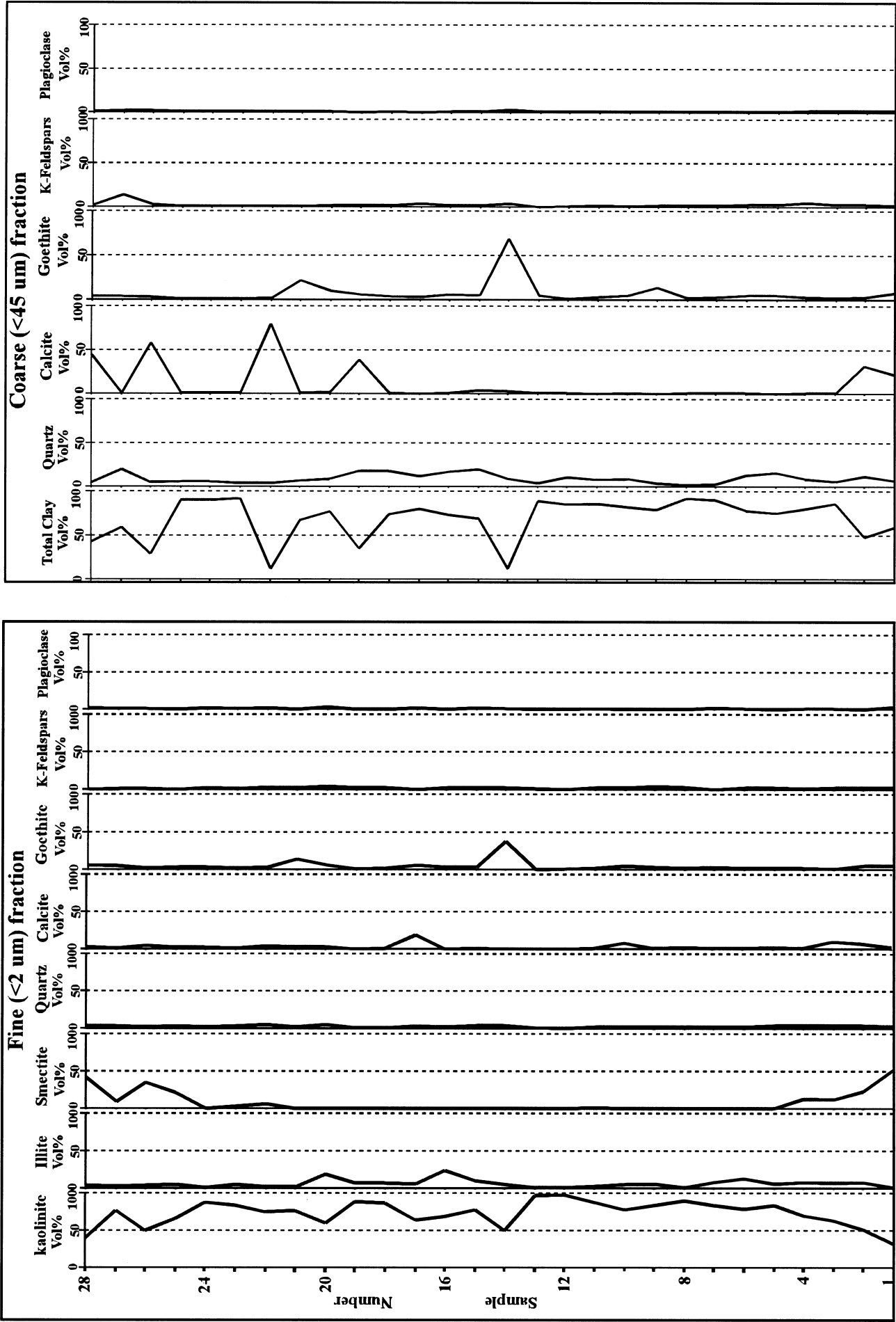
Table 1. Results of semiquantitative (vol\%) of XRD analyses. Peak intensities indicated by the integrated peak areas are used to determine the relative abundance of the oriented $<2 \mu \mathrm{m}$ fractions, whereas peak heights are used for the $<45 \mu \mathrm{m}$ fractions.

\begin{tabular}{|c|c|c|c|c|c|c|c|c|c|c|c|c|c|c|c|}
\hline \multirow[t]{2}{*}{$\mathrm{Fm}$} & \multirow{2}{*}{$\begin{array}{c}\text { Sample } \\
\text { No. }\end{array}$} & \multicolumn{8}{|c|}{$<2 \mu \mathrm{m}$ (fine) Fraction } & \multicolumn{6}{|c|}{$<45 \mu \mathrm{m}$ (coarse) Fraction } \\
\hline & & Kao & Illite & $\mathrm{Sm}$ & Qz & $\mathrm{Cal}$ & Goet & Fels & Plag & Clays & $\mathrm{Qz}$ & $\mathrm{Cal}$ & Goet & Fels & Plag \\
\hline \multicolumn{16}{|c|}{ Safa Formation } \\
\hline & 28 & 40 & 4 & 42 & 3 & 3 & 6 & - & 2 & 43 & 5 & 45 & $<5$ & 2 & 1 \\
\hline & 27 & 77 & 3 & 9 & 3 & $<3$ & 5 & 1 & 1 & 59 & 20 & $<3$ & $<5$ & 14 & 2 \\
\hline & 26 & 50 & 4 & 35 & 2 & 5 & $<5$ & 1 & 1 & 29 & 5 & 58 & $<5$ & 3 & 2 \\
\hline & 25 & 66 & 5 & 21 & 3 & $<3$ & $<5$ & - & - & 90 & 6 & $<3$ & $<5$ & 1 & 1 \\
\hline & 24 & 88 & $<5$ & - & 2 & $<3$ & $<5$ & 2 & 2 & 90 & 6 & $<3$ & $<5$ & 1 & 1 \\
\hline & 23 & 84 & 5 & $<5$ & 3 & $<3$ & $<5$ & 1 & 1 & 92 & 4 & $<3$ & $<5$ & 1 & 1 \\
\hline & 22 & 75 & $<5$ & 6 & 5 & 4 & $<5$ & 3 & 2 & 12 & 4 & 80 & $<5$ & 1 & 1 \\
\hline & 21 & 77 & $<5$ & - & 2 & 3 & 14 & 2 & - & 67 & 7 & $<3$ & 22 & 1 & 1 \\
\hline & 20 & 60 & 19 & - & 5 & 3 & 6 & 4 & 3 & 77 & 9 & $<3$ & 10 & 2 & 1 \\
\hline & 19 & 89 & 7 & - & 1 & - & $<5$ & 2 & - & 35 & 18 & 39 & 6 & 2 & - \\
\hline & 18 & 87 & 7 & - & 1 & $<3$ & $<5$ & 2 & - & 74 & 18 & $<3$ & $<5$ & 2 & 1 \\
\hline & 17 & 64 & 6 & - & 3 & 19 & 6 & - & 2 & 80 & 12 & - & $<5$ & 4 & - \\
\hline & 16 & 69 & 24 & - & 2 & - & $<5$ & 2 & - & 73 & 17 & $<3$ & 6 & 2 & 1 \\
\hline & 15 & 78 & 10 & - & 4 & $<3$ & $<5$ & 2 & 2 & 69 & 20 & 4 & 5 & 2 & 1 \\
\hline & 14 & 50 & 5 & - & 4 & - & 38 & 2 & 1 & 12 & 9 & 3 & 69 & 4 & 3 \\
\hline & 13 & 97 & $<5$ & - & 1 & - & - & 1 & - & 89 & 4 & $<3$ & 5 & - & 1 \\
\hline & 12 & 98 & $<5$ & - & - & - & $<5$ & - & - & 85 & 11 & $<3$ & $<5$ & 1 & 1 \\
\hline & 11 & 88 & $<5$ & $<5$ & 2 & $<3$ & $<5$ & 2 & 1 & 86 & 8 & - & $<5$ & 2 & 1 \\
\hline & 10 & 78 & 5 & - & 2 & 8 & 5 & 2 & - & 82 & 9 & $<3$ & 5 & 1 & 1 \\
\hline & 9 & 84 & 6 & - & 2 & $<3$ & $<5$ & 4 & - & 79 & 4 & - & 14 & 2 & 1 \\
\hline & 8 & 90 & $<5$ & - & 2 & $<3$ & $<5$ & 3 & - & 92 & 2 & $<3$ & $<5$ & 2 & 1 \\
\hline & 7 & 84 & 8 & - & 2 & $<3$ & $<5$ & - & 2 & 90 & 3 & $<3$ & $<5$ & 2 & 1 \\
\hline & 6 & 79 & 13 & - & 2 & $<3$ & $<5$ & 2 & 1 & 78 & 13 & $<3$ & 5 & 3 & 1 \\
\hline & 5 & 84 & 6 & & 4 & $<3$ & $<5$ & 2 & - & 75 & 16 & - & 5 & 3 & 1 \\
\hline & 4 & 70 & 8 & 13 & 4 & $<3$ & $<5$ & 1 & 1 & 80 & 9 & $<3$ & $<5$ & 5 & 2 \\
\hline & 3 & 63 & 7 & 12 & 4 & 10 & $<5$ & 2 & 1 & 86 & 6 & $<3$ & $<5$ & 3 & 2 \\
\hline Bir & 2 & 51 & 8 & 23 & 4 & 7 & 5 & 2 & - & 48 & 12 & 32 & $<5$ & 3 & 2 \\
\hline Magh. & 1 & 32 & $<5$ & 52 & 3 & $<3$ & 5 & 2 & 3 & 59 & 7 & 22 & 8 & 2 & 2 \\
\hline
\end{tabular}

Kao: Kaolinite; Sm: Smectite; Qz: Quartz; Cal: Calcite; Goet: Goethite; Fels: K-Feldspars; Plag: Plagioclase, (-): not detected.

tration of $1 \mathrm{vol} \%$ in the two fractions. Calcite is the only detected carbonate mineral. Its concentration relative to other non-clay minerals varies from $<3$ to $80 \mathrm{vol} \%$ with an average of $11 \mathrm{vol} \%$ in the $<45 \mu \mathrm{m}$ fractions, whereas it ranges from $<3$ to $19 \mathrm{vol} \%$ (averaging $3 \mathrm{vol} \%$ ) in the fine fractions. Marine shales contain relatively higher calcite content than non-marine shales. Calcite varies from 22 to 80 vol\% in marine shales, while values less than 4 vol\% were detected in non-marine shales. Goethite was detected in all studied samples. The highest content of goethite was obtained from sample No. 14 in the middle part of the Safa Formation, in which 69 vol\% and 38 vol\% of goethite are found in the coarse and fine fractions, respectively.

The clay minerals identified in the $<2 \mu \mathrm{m}$ fractions are kaolinite, illite, and smectite. Kaolinite is generally the dominant clay mineral in most of the studied samples, especially those from the Safa Formation. The proportion of kaolinite ranges from 32 to 98 vol\%, with an average of 73 vol\%. The dominance of kaolinite in the Safa Formation is in agreement with the results obtained by El-Anbaawy and Youssef (1989) and Abd El-Hameed (1997). Samples from the Bir Maghara Formation and from the upper Safa Formation yielded relatively lower kaolinite content 


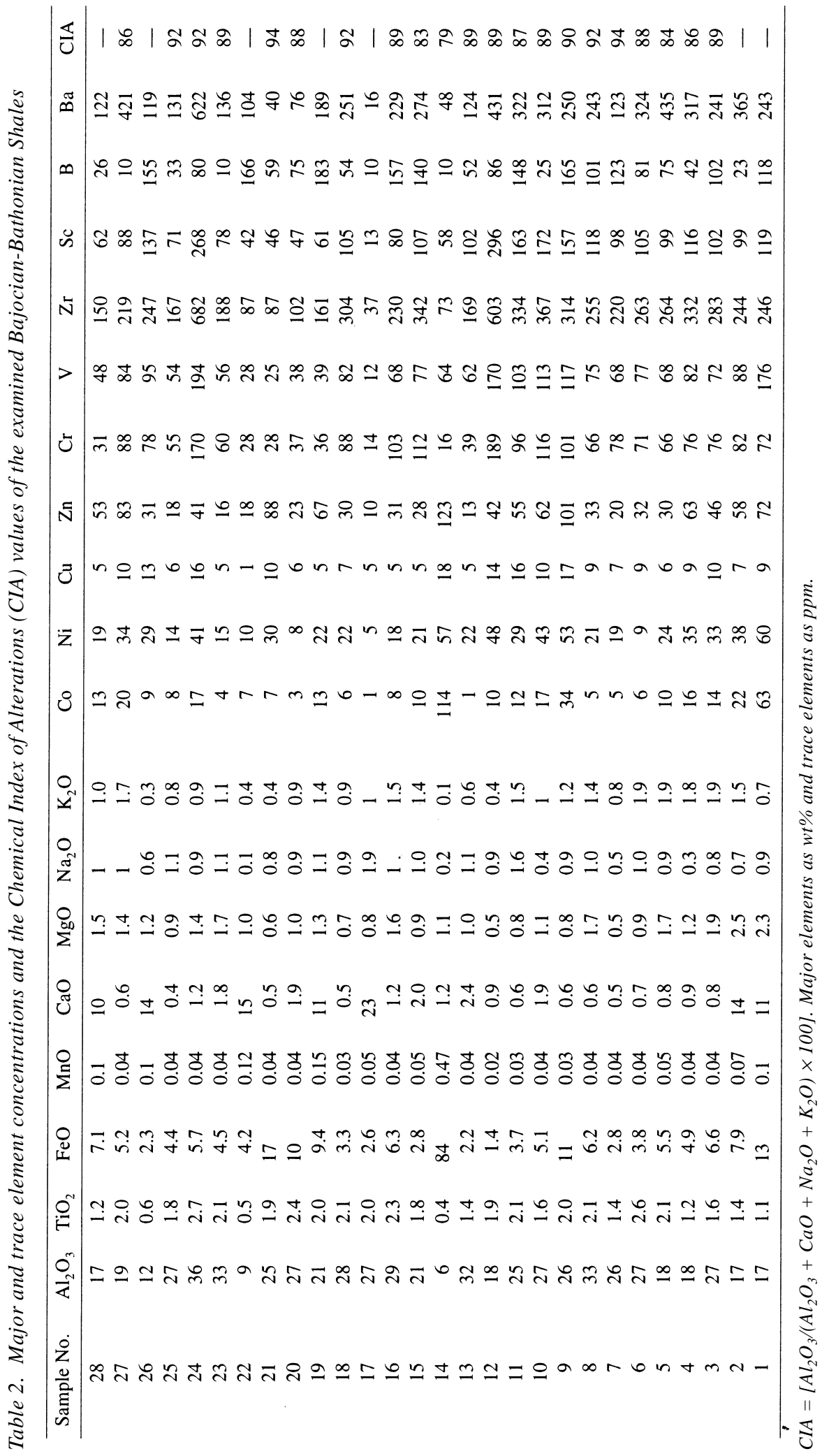



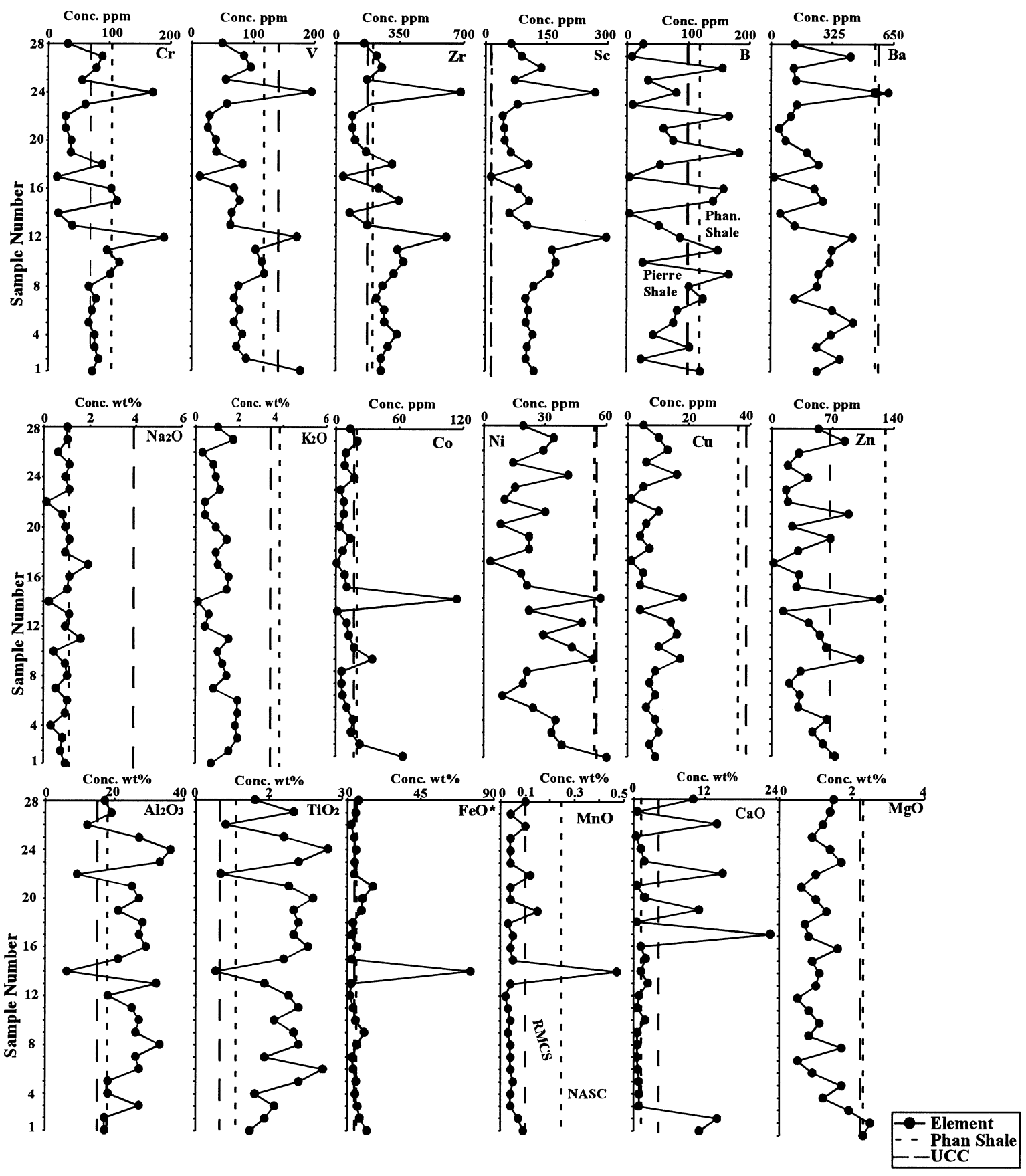

Fig. 5. Vertical variations in the major and trace element concentrations through the Bajocian-Bathonian shales. The elemental concentrations are plotted against the average compositions of common shale composites and the UCC. Figure is not scaled (see Fig. 2. for sampling intervals and the sample's position. 
compared with the other samples. Illite is detected in all of the studied samples with low abundances varying from $<5$ to $24 \mathrm{vol} \%$ and averaging $6 \mathrm{vol} \%$. Smectite, on the other hand, was found only in a few cases. Its relative proportion ranges from $<5$ to $52 \mathrm{vol} \%$, with an average of $8 \mathrm{vol} \%$. It is noteworthy that the smectite abundance is related to the depositional environment; higher concentrations of smectite are obtained from marine shales (samples from the Bir Maghara Formation and the upper part of the Safa formations), whereas nonmarine shales have no smectite or low contents.

\section{Geochemistry}

The major and trace element concentrations of the studied shales are displayed in Table 2 and Fig. 5. For comparison, the chemical composition of the studied shales is plotted against the chemical composition of previously studied common shale composites (Schultz et al., 1980; Gromet et al., 1984; Condie, 1993) and the Upper Continental Crust (UCC) (Taylor and McLennan, 1985); see Table 3 and Fig. 5.
Major elements The $\mathrm{Al}_{2} \mathrm{O}_{3}$ concentrations range from 6 to $36 \mathrm{wt} \%$, with an average of $23 \mathrm{wt} \%$, and the $\mathrm{TiO}_{2}$ contents range from 0.4 to $2.7 \mathrm{wt} \%$, averaging $1.7 \mathrm{wt} \%$. The $\mathrm{CaO}$ content ranges between 0.4 to $15 \mathrm{wt} \%$ and averages $3.5 \mathrm{wt} \%$, whereas $\mathrm{MgO}$ concentrations vary from 0.5 to 2.5 wt $\%$, with an average $1.2 \mathrm{wt} \%$. The $\mathrm{K}_{2} \mathrm{O}$ and $\mathrm{Na}_{2} \mathrm{O}$ concentrations range from 0.3 to $1.9 \mathrm{wt} \%$ and 0.2 to $1.9 \mathrm{wt} \%$, respectively. The $\mathrm{FeO}^{*}$ content generally ranges from 1.4 to $17 \mathrm{wt} \%$ and averages 8.6 wt $\%$. Extremely high $\mathrm{FeO} *(84 \mathrm{wt} \%$ ) concentration was obtained from a goethite-rich horizon (30-cm-thick) in the middle part of the Safa Formation. The $\mathrm{MnO}$ contents range from 0.02 to 0.47 wt $\%$, with an average of $0.07 \mathrm{wt} \%$.

The Chemical Indices of Alteration (CIA) after Nesbitt and Young (1982), vary from 79 to 94, indicating that the degree of chemical weathering varies considerably. Six samples, four from the Safa Formation and two from the Bir Maghara Formation, which yielded low CIA values $(<61)$, are excluded as they are enriched in calcite. The high CIA values in the studied shales probably

Table 3. The average chemical composition of the studied shales in comparison with the average chemical composition of different shale composites

\begin{tabular}{lccccccccc}
\hline Elements & Average & $\begin{array}{c}\text { Minimum } \\
\text { value }\end{array}$ & $\begin{array}{c}\text { Maximum } \\
\text { value }\end{array}$ & $\begin{array}{c}\text { Standard } \\
\text { deviation }\end{array}$ & Phan Sh & UCC & $\begin{array}{c}\text { Pierre } \\
\text { shale }\end{array}$ & NASC & RMCS \\
\hline $\mathrm{Al}_{2} \mathrm{O}_{3}$ & 23 & 6 & 36 & 7.32 & 17.8 & 15.0 & 16 & 17.05 & 16.7 \\
$\mathrm{TiO}_{2}$ & 1.7 & 0.4 & 2.7 & 0.59 & 0.8 & 0.5 & 0.65 & 0.8 & 0.8 \\
$\mathrm{FeO}$ & 8.7 & 1.4 & 84 & 15.18 & 5.9 & 4.5 & 1.1 & 5.7 & 6 \\
$\mathrm{MnO}$ & 0.1 & 0.02 & 0.47 & 0.08 & & & & 0.25 & 0.1 \\
$\mathrm{CaO}$ & 4.3 & 0.4 & 23 & 6.1 & 1.3 & 4.2 & 1.2 & 3.51 & 5.7 \\
$\mathrm{MgO}$ & 1.2 & 0.5 & 2.5 & 0.51 & 2.3 & 2.2 & 2.1 & 2.83 & 2.5 \\
$\mathrm{Na} 2$ & 0.9 & 0.1 & 1.9 & 0.37 & 1.1 & 3.9 & 1.1 & 1.13 & 2.7 \\
$\mathrm{~K}_{2} \mathrm{O}$ & 1.1 & 0.1 & 1.9 & 0.52 & 3.8 & 3.4 & 2.6 & 3.97 & 2.7 \\
$\mathrm{Co}$ & 16 & 0.4 & 114 & 22.69 & 20 & 17 & 13 & & \\
$\mathrm{Ni}$ & 28 & 3 & 60 & 14.98 & 54 & 55 & 39 & 36 & \\
$\mathrm{Cu}$ & 9 & 1 & 18 & 4.6 & & 39 & 36 & \\
$\mathrm{Zn}$ & 46 & 2 & 2 & 123 & 28.8 & & 130 & & \\
$\mathrm{Cr}$ & 74 & 14 & 189 & 41.27 & 104 & 69 & 90 & & \\
$\mathrm{~V}$ & 80 & 12 & 194 & 43.38 & 117 & 140 & 170 & & \\
$\mathrm{Zr}$ & 249 & 37 & 682 & 142.06 & 201 & 170 & 170 & & \\
$\mathrm{Sc}$ & 108 & 13 & 296 & 61.81 & 16 & 14 & 18 & \\
$\mathrm{~B}$ & 82 & 3 & 183 & 56.50 & 100 & & 118 & \\
$\mathrm{Ba}$ & 232 & 16 & 622 & 142.34 & 551 & 570 & 730 & \\
\hline
\end{tabular}

Phan Sh: Phanerozoic Shales (Condie, 1993), UCC: Upper Continental Crust (Taylor and McLennan, 1985), Pierre Shale (Schultz et al., 1980), NASC: North American Shale Composites (Gromet et al., 1984) and RMCS: Russian Mesozoic and Cenozoic Shales (Ronov and Migdisov, 1971). 
reflect the presence of clay minerals and absence of detrital feldspars (Nyakairu and Koeberl, 2001). Trace elements Analytical results of the trace elements, $\mathrm{Co}, \mathrm{Ni}, \mathrm{Cu}, \mathrm{Zn}, \mathrm{V}, \mathrm{Cr}, \mathrm{Zr}, \mathrm{Sc}, \mathrm{B}$ and $\mathrm{Ba}$ are summarised in Table 2 and shown Fig. 5. Similar to the major elements, variations of the trace element composition have no specific stratigraphic trend. Zirconium (Zr), Sc and B contents are extremely high and are enriched if compared with other shales. $\mathrm{Zr}$ concentrations vary from 37 to $367 \mathrm{ppm}$, with an average of $249 \mathrm{ppm}$. About two thirds of the studied samples are enriched in $\mathrm{Zr}$ and yielded concentrations larger than those recorded from the common shale composites. Samples 12 and 24 yielded abnormally high Zr concentrations, i.e., 603 and $682 \mathrm{ppm}$, respectively. Sc concentrations on the other hand, vary from 13 to $172 \mathrm{ppm}$, averaging $108 \mathrm{ppm}$. Almost all of the studied samples are strongly enriched in Sc compared with the average Sc contents in the Phanerozoic Shales (16 ppm) (Condie, 1993) and in the UCC (14 ppm) (Taylor and McLennan, 1985). Similar to Zr, samples 12 and 24 gave extremely high Sc concentrations -268 and 296 ppm respectively. The boron (B) content varies from 3 to $183 \mathrm{ppm}$, and averages $82 \mathrm{ppm}$. Barium (Ba) contents range from 16 to $435 \mathrm{ppm}$ with an average of $232 \mathrm{ppm}$. The highest Ba value (622 ppm) was obtained from the upper part of the Safa Formation. The majority of other trace elements were encountered with average concentrations relatively lower than those recorded from common shale composites. The average concentrations of $\mathrm{Co}, \mathrm{Ni}, \mathrm{Cu}, \mathrm{Zn}, \mathrm{Cr}$ and $\mathrm{V}$ are 16, 28, 9, 46, 74 and $80 \mathrm{ppm}$, respectively.

\section{DISCUSSION}

\section{Controlling factors of clay mineral distribution}

Bajocian-Bathonian shales at G. Al-Maghara, North Sinai, Egypt, yield clay mineral assemblage dominated by kaolinite with subordinate quantities of illite and sporadic occurrences of smectite. Neither chlorite nor mixed-layers were found in the studied shales. Climatic conditions, hydraulic sorting and relative sea-level changes seem to be the major controlling factors for the clay mineral assemblage of these shales.

Kaolinite, the dominated clay mineral in the studied shales, has been accepted for long time as a product of chemical weathering of feldspars. Kaolinite formation is favoured under tropical to subtropical humid climatic conditions (Chamley, 1989; Hallam et al., 1991). In addition to the detrital origin, kaolinite may also develop by diagenetic processes due to the circulation of acid solutions and that may hinder the use of kaolinite as a paleoclimatic indicator. Füchtbauer (1964) had reported neoformation of kaolinite in the Molasse Basin. Hoffman and Hower (1979) referred to the mineralogical criteria for shale diagenesis, which include i) conversion of smectite to illite through mixed layer, ii) the appearance of chlorite and iii) disappearance of Kfeldspars as a result of decomposition. The average vitrinite reflectance of the subsurface Bathonian shales and the interbedded coals of $\mathrm{G}$. Al-Maghara is $0.44 \%$, whereas the Rock Eval Tmax values are $417^{\circ} \mathrm{C}$ and $428^{\circ} \mathrm{C}$ for coal and shale, respectively (Mostafa and Younes, 2001). This suggests that the Bathonian shales at G. AlMaghara are generally immature for oil generation. Generally, mudstones which are immature for oil generation, contain discrete minerals predominantly of detrital origin reflecting largely the character of parent rocks (Lindgreen and Surlyk, 2000). The transformation of illite-smectite often takes place at the temperature of oil formation (Perry and Hower, 1970). In diagenesis, the morphology of kaolinite changes from vermicular or aggregates of books to individual blockier crystals (Ehrenberg et al., 1993). However, there is no evidence for the role of diagenesis in the production of clay minerals in the studied shales. The SEM observations show a swirly texture with face to face arrangement of clay grains (Fig. 6a), suggesting detrital origin (Keller, 1978; Manju et al., 2001). Furthermore, kaolinite occurs as discrete, poorly crystallized clasts with angular and irregular periphery (Fig. 6b). The characteristic vermicular and booklet shape of authigenic kaolinite, as well as the blocky crystals of diagenetic kaolinite, 
are completely absent.

Smectite formation, on the other hand, favours conditions of pronounced dry seasons alternating with less pronounced wet seasons (Singer, 1984). Numerous mineralogical and chemical studies of smectitic minerals suggested that smectite from most Mesozoic sediments were mainly soil-derived minerals (Chamley, 1989). Smectite may be volcanogenic in origin (Hallam et al., 1991), being derived directly from the weathering and alteration of volcanic materials and thus has no climatic significance. Bartov et al. (1980) showed that volcanic activity was associated with rift basin formation during Jurassic in North Africa. However, the volcanogenic origin of smectite would be excluded due to the absence of associated accessory minerals like biotite, sphene, relict glass shards, etc. (Pacey, 1984).

Illite typically forms under conditions completely different from those under which kaolinite and smectite are formed. Illite typically forms in soils with little chemical weathering in cold and/ or dry climates, and in areas of high relief where physical erosion is predominant. The relatively lower illite contents of the studied shales are produced by physical erosion of illite-bearing source rocks. Illite has no climatic significance, but Singer (1984) attributed the high illite crystallinity to cold or dry climatic conditions with mini- mum hydrolysation.

The relative abundance of kaolinite to smectite is clearly influenced by hydraulic sorting and relative sea level changes. Kaolinite tends to concentrate in sediments of non-marine and marginal marine settings, whereas smectite was reported to have higher relative abundance from normal marine shales. This would be attributed to the hydraulic segregation of clay minerals (Raucsik and Merényi, 2000). Kaolinite and illite tend to concentrate in relatively near-shore shallow water settings, reflecting their coarse-grained nature and their strong tendency to flocculate compared to smectite, whereas smectite tends to settle as finer particles in deeper offshore settings. Ghandour (1998) recorded high relative kaolinite contents in the Paleocene sediments at Esna region in Central Egypt, whereas relatively higher smectite contents were recorded in the Qena and Kharga areas. The Paleocene paleoshoreline indicates that the Esna area was shallower than the Qena and Kharga areas (Speijer, 1994). Deconinck et al. (1985) used the relative proportions of illite/ kaolinite to smectite in Malm-Cretaceous marine sediments of France to infer shallowing/regressive and deepening/transgressive episodes, respectively. Lindgreen and Surlyk (2000) attributed the decrease in kaolinite content towards the end of Jurassic to differential sorting as a result of the
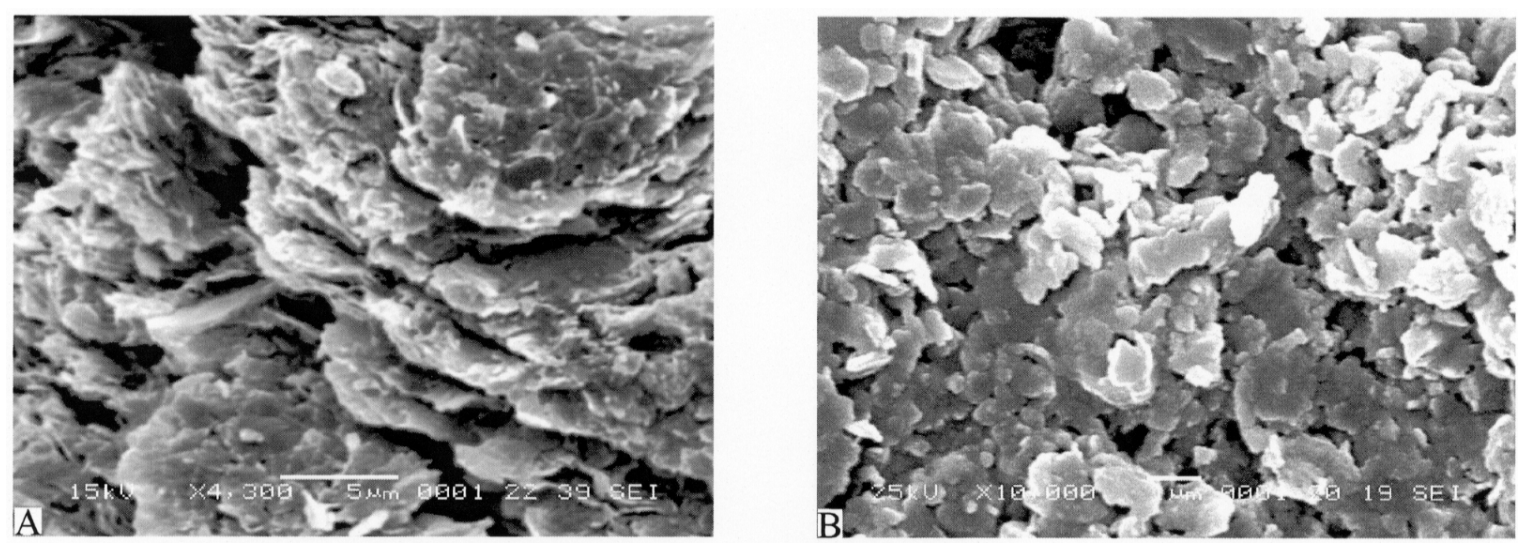

Fig. 6. Scanning electron photographs of the Bajocian-Bathonian shales: A) Swirl texture with face to face arrangement of coarse detrital kaolinite. B) Detrital platelets of kaolinite with irregular and angular edges. 
long distances from the source rock and not due to climatic controls, as was suggested by Hallam et al. (1991).

Relative sea-level changes affected the distribution of smectite relative to kaolinite. Sediments of the Bir Maghara Formation were deposited under different sea level conditions (Ghandour, in prep.). The shale bed from which sample No. 1 was taken was deposited during a sea level highstand (High-stand Systems Tracts). At such highstand, the terrigenous influx is limited, as it is trapped landwards (Van Wagoner et al., 1990) and, therefore, relatively higher amounts of smectite are observed, as there is no dilution of smectite by other terrigenous minerals. With the onset of a sea level fall (the uppermost shale of Bir Maghara Formation and the lowermost part of Safa Formation), high terrigenous influx is delivered to a deeper region, increasing the abundance of kaolinite relative to smectite.

\section{Factors controlling chemical composition}

Elemental concentrations in sediments result from the competing influences of provenance, weathering, diagenesis, and sediment sorting (Quinby-Hunt et al., 1991). The chemical composition of Bajocian-Bathonian shales of G. AlMaghara is strongly affected by weathering and the chemistry of the source rocks, processes of transportation, and the dominant mineral composition.

When comparing with the chemical composition of the classic shale composites and the Upper Continental Crust (Table 3), the studied shales show enrichments of elements that are chemically immobile and are associated with terrigenous influx, such as Al, Ti, Zr and Sc. Al and Ti are chemically immobile and can survive throughout intensive chemical weathering and diagenesis (Cullers, 2000). Their concentrations in sediments are used as a measure of detrital input. The average $\mathrm{Al}_{2} \mathrm{O}_{3}$ concentration of the studied shales is $23 \mathrm{wt} \%$ (Table 4), whereas the average $\mathrm{Al}_{2} \mathrm{O}_{3}$ concentrations in the Phanerozoic Shales and the Upper Continental Crust (UCC) are 17.8 and $15 \mathrm{wt} \%$, respectively (Condie, 1993; Taylor and McLennan,
1985). Manju et al. (2001) detected high $\mathrm{Al}_{2} \mathrm{O}_{3}$ concentrations - up to $37.3 \mathrm{wt} \%$ - in the kaoliniterich Madayi deposits in India. The $\mathrm{Al}_{2} \mathrm{O}_{3}$ content correlates well with the clay content (correlation coefficient $r=0.8$ ) of the studied shales (Table 4). Kaolinite, the most dominant clay mineral in the studied shales, accommodates only $\mathrm{Si}$ and $\mathrm{Al}$ and forms only in acidic environments where all bases tend to be removed in solution. Kaolinite formation is promoted when chemical weathering processes tend to remove silica from solution, thereby enriching the residue in $\mathrm{Al}_{2} \mathrm{O}_{3}$ (Mason and Moore, 1982). The studied shales have $1.7 \mathrm{wt} \%$ average $\mathrm{TiO}_{2}$ concentrations, whereas Phanerozoic Shale and UCC have $0.8 \mathrm{wt} \%$ and $0.5 \mathrm{wt} \%$, respectively (Condie, 1993; Taylor and McLennan, 1985). In general, the Ti content in the sediments is influenced by the composition of the source rock which contain Ti-bearing minerals (e.g., ilmenite and rutile) and the rate of chemical weathering, which is related to the dominant climate (Schroeder and Shiflet, 2000). The enrichment of titanium and aluminium and the strong positive correlation ( $r=0.8)$ between the two elements could be attributed to the effect of chemical weathering and we suggest that $\mathrm{Ti}$ is contained mainly in phyllosilicates rather than Ti-bearing minerals (Condie et al., 1992). On the other hand, other major oxides were detected with relatively lower average concentrations compared to common shale composites and UCC. Chemical weathering of the source rocks played a major role in this depletion. Generally, the studied shales are strongly depleted in $\mathrm{CaO}, \mathrm{MgO}, \mathrm{Na}_{2} \mathrm{O}$ and $\mathrm{K}_{2} \mathrm{O}$ compared to the Phanerozoic Shales and the UCC. Higher $\mathrm{CaO}$ values were obtained only from calcite-rich marine shales. $\mathrm{Ca}, \mathrm{K}$ and $\mathrm{Na}$ tend to be removed from feldspars by aggressive soil solution, contributing to a high $\mathrm{Al}$ proportion relative to the alkalis. Increased weathering tends to produce high-Al minerals, such as kaolinite (Visser and Young, 1990). Iron content has average concentration $(5.8 \mathrm{wt} \%)$, more or less similar to the average iron concentrations in the Phanerozoic Shales (5.9 wt\%) (Condie, 1993) and slightly higher than the average iron content in the UCC 


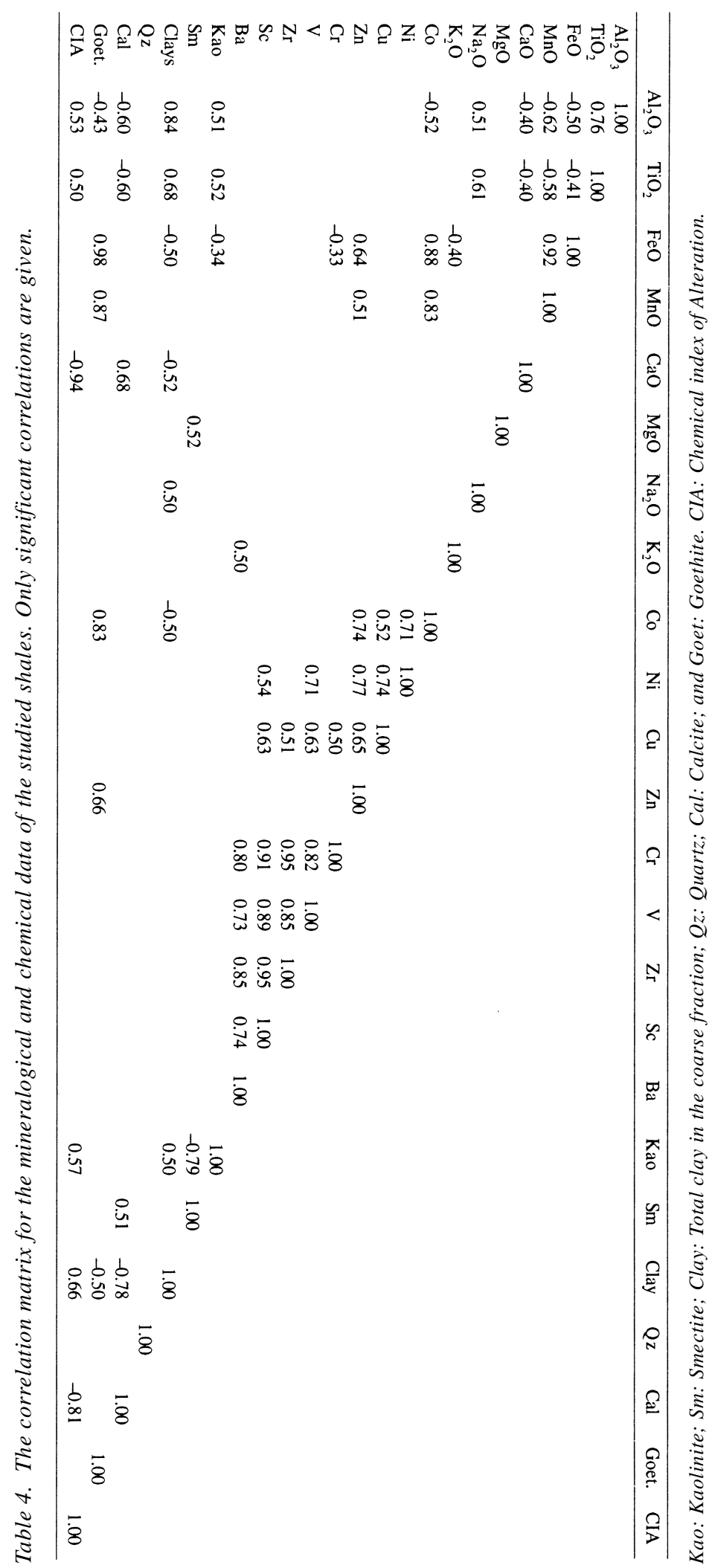


(4.5 wt\%) (Taylor and McLennan, 1985). FeO* concentrations in the studied shales vary from 2.2 to $13 \mathrm{wt} \%$. The highest iron concentration (84 $\mathrm{wt} \%)$ was obtained from a goethite-rich horizon (30-cm-thick) in the middle part of the Safa Formation. Macquaker et al. (1997) noticed that during weathering ferric iron and $\mathrm{Al}$ accumulate relative to other common elements because of the extreme insolubility of their oxides and hydroxides. However, under acidic conditions, $\mathrm{Al}^{3+}$ can be fixed as kaolinite and $\mathrm{Fe}^{3+}$ can move easier than Al. In the present study, the aluminium content is negatively correlated (Table 4) with the iron content $(r=-0.5)$. It seems that iron is transported from the source area in a dissolved ferrous form and later recrystallizes in the form of goethite. This is also indicated by the negative relationship between the total clay and goethite contents $(r=$ $-0.5)$.

The Chemical Index of Alteration (CIA) (Nesbitt and Young, 1982) indicates that $80 \%$ of the studied sediments (all from Safa Formation) had experienced strong chemical weathering $(\mathrm{CIA}>76)$ at the source area. The CIA is positively correlated with the total clay $(r=0.7)$ and kaolinite $(r=0.6)$ contents (Table 4$)$. Nyakairu and Koeberl (2001) recorded high CIA values (87 to 96) and low contents of alkali elements from kaolinite rich sediments from Central Uganda. They related these high values to the intensive weathering of source rock. Nesbitt and Young (1982) and Nyakairu and Koeberl (2001) used a ternary diagram $\mathrm{Al}_{2} \mathrm{O}_{3}-\mathrm{CaO}+\mathrm{Na}_{2} \mathrm{O}-\mathrm{K}_{2} \mathrm{O}(\mathrm{A}-\mathrm{CN}$ $\mathrm{K})$ to infer the weathering history at the source area. Plotting chemical data from the studied shales on a ternary diagram (Fig. 7), excluding samples enriched in calcite, indicate that the remaining samples reveal indications of strong chemical weathering.

The trace element composition of the studied shales is influenced by the source rock chemistry and weathering history, sedimentary recycling, and transportation. The trace elements behave in different ways during chemical weathering. $\mathrm{Zr}$, Sc and $\mathrm{Cr}$ are among the least soluble trace elements and are relatively immobile during chemical

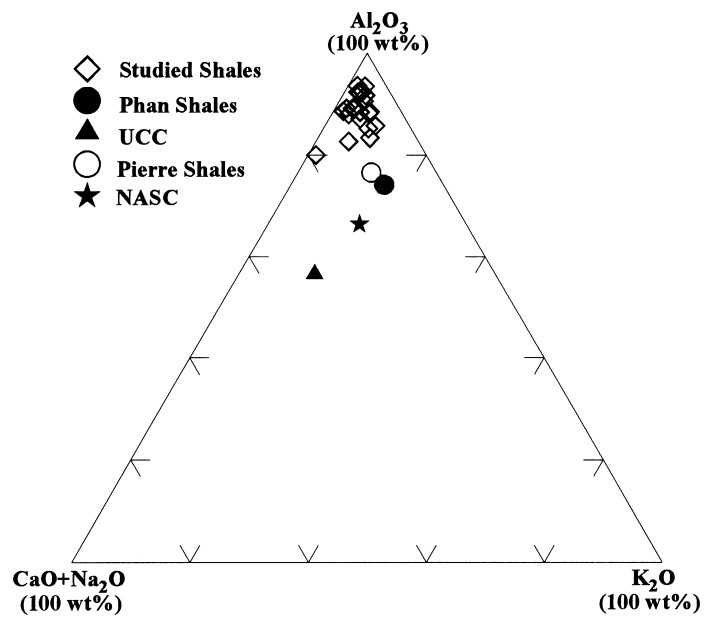

Fig. 7. $\mathrm{Al}_{2} \mathrm{O}_{3}-\mathrm{CaO}+\mathrm{Na}_{2} \mathrm{O}-\mathrm{K}_{2} \mathrm{O}$ plot of the studied shale samples excluding samples enriched in calcite. The present data are compared with Phanerozoic Shales (Condie, 1993), UCC (Taylor and MeLennan, 1985), Pierre Shale (Schultz et al., 1980) and NASC (Gromet et al., 1984).

weathering and diagenesis. These elements are believed to be transported exclusively in the terrigenous component of the sediments and therefore reflect the chemistry of the source rock (Rollinson, 1993). About two thirds of the studied sediments are enriched in $\mathrm{Zr}$. The average $\mathrm{Zr}$ concentration of the studied shales is $249 \mathrm{ppm}$, whereas Phanerozoic Shales and UCC give average $\mathrm{Zr}$ concentrations of $201 \mathrm{ppm}$ and $170 \mathrm{ppm}$, respectively. $\mathrm{Zr}$ is generally transported with terrigenous influx in the form of heavy mineral (zircon). Zircon was not detected in either the fine or coarse fractions by X-ray diffraction. This can be attributed to the low concentration of zircon in size fractions coarser than $45 \mu \mathrm{m}$. In addition to the enrichment of $\mathrm{Zr}$ during chemical weathering, sediment recycling is also responsible for such enrichments. Scandium (Sc), on the other hand, is extremely enriched in the studied shales if compared with common shale composites and UCC. The average Sc concentration of the studied shales is $108 \mathrm{ppm}$ (Table 3), whereas common shales and UCC give Sc average concentrations not exceeding 22 ppm (Condie, 1993). The high Sc contents of the studied shales are due to the weathering of 
a Sc-rich source rock. Vital et al. (1999) found average Sc concentrations of up to $128 \mathrm{ppm}$ from the heavy mineral fraction of sediments from the lowermost Amazon River. Sc-enrichments were also reported in fresh and weathered carbonatites (Kravchenko et al., 1996) and in lateritic weathered crust (Australian Rare Earth Newsletter Website, 2001). Bernhard (2001) related the enrichment of Sc at eastern Alps to the formation of Lazulite-quartz veins associated with PermoTriassic extensional tectonics. The chromium (Cr) concentrations barely exceed the average $\mathrm{Cr}$ concentrations of the Phanerozoic Shale (Table 3), whereas the majority of the studied samples are exceeding the average $\mathrm{Cr}$ concentration in the UCC. Cr was presumably derived from a source dominated by mafic volcanic rocks (Gill, 1981). $\mathrm{High} \mathrm{Cr}$ and $\mathrm{Ni}$ concentrations and strong positive correlations between the two elements have been used as an indicator of mafic and ultramafic provenance (Garver et al., 1996). The concentrations of $\mathrm{Cr}$ and $\mathrm{Ni}$ in shales are further reflect the incorporation of $\mathrm{Cr}$ and $\mathrm{Ni}$ ions to clay particles during weathering of ultramafic rocks containing chromite and other $\mathrm{Cr}$ and $\mathrm{Ni}$-bearing minerals (Garver et al., 1996). Levels enriched in Cr may indicate that mafic to ultramafic components were among the source rocks.

Vanadium (V) concentrations are relatively lower than the levels commonly recorded in common shales and in the UCC. Vanadium varies from 12 to $194 \mathrm{ppm}$ with an average $80 \mathrm{ppm}$. Vanadium (V) is enriched in organic rich shales that are deposited under reducing conditions. $\mathrm{V}$ also may be hosted by detrital silicate minerals (Stow and Atkin, 1987). The $\mathrm{V} / \mathrm{Cr}$ ratio has been used as a paleo-oxygenation indicator in a number of studies. Values of $\mathrm{V} / \mathrm{Cr}>2$ are thought to represent anoxic depositional conditions, whereas values below 2 are indicative of more oxidizing conditions (Dill et al., 1988). The studied shales have $\mathrm{Cr} / \mathrm{V}$ values of $<2$, which may indicate that all of the studied sediments were deposited under relatively oxidizing conditions.

The $\mathrm{Zr}$ contents show strong positive correlations with Sc $(r=0.95), \mathrm{Cr}(r=0.94)$ and $\mathrm{V}(r=$
$0.85)$. This may indicate that the source rock probably suffered from intensive chemical weathering (Wronkiewicz and Condie, 1989). Ferromagnesian trace elements $(\mathrm{Cr}, \mathrm{Ni}, \mathrm{V}, \mathrm{Co}$ and $\mathrm{Sc}$ ) have reasonably positive interrelationships. $\mathrm{Cr}$ has strong positive correlation with $\mathrm{V}(r=0.8)$ and $\mathrm{Sc}(r=$ $0.9)$. Ni on the other hand, correlates well with $\mathrm{V}$ and Co $(r=0.7)$ and badly with Sc $(r=0.5)$. Vanadium (V) correlates strongly with Sc $(r=0.9)$. Ferromagnesian trace elements are weakly correlated with $\mathrm{Al}_{2} \mathrm{O}_{3}$. Meanwhile, these elements are strongly correlated with $\mathrm{Zr}$. This indicates that these elements are mainly controlled by the concentration of accessory non-aluminous silicate (except detrital zircon) minerals and partly controlled by the abundance of clay minerals. This is further illustrated by the weak to moderate correlation with total clay minerals and kaolinite content.

\section{Climatic Interpretations}

The studied succession is well suited for inferring the Middle Jurassic paleoclimatic conditions. Generally, the studied succession is composed dominantly of siliciclastic sediments with abundant plant remains intercalated with carbonates. According to the climate-driven scenario, lithologic changes reflect climatic changes, where humid periods resulted in high runoff and siliciclastic deposition, and arid periods resulted in evaporation and carbonate deposition (Brookfield, 1973; Ruffell and Rawson, 1994). The carbonate rocks show the same age as siliciclastic rocks in the Corallian strata in southern England, implying that carbonate rocks may be formed under both humid and arid periods (De Wet, 1998). However, widespread arid conditions would be excluded during BajocianBathonian time, as supported by the noticeable absence of evaporate minerals.

Integration of mineralogical and chemical data obtained in this study reveals that the climatic conditions play a major role in the production of the studied Bajocian-Bathonian shales. There are several parameters in the studied sediments that can be used as paleoclimatic indicators. These param- 
eters include the high kaolinite content, enrichment of chemically immobile elements $\left(\mathrm{Al}_{2} \mathrm{O}_{3}\right.$, $\mathrm{TiO}_{2}, \mathrm{Zr}$ and $\mathrm{Sc}$ ) with the depletion of other mobile elements, and relatively higher values of the Chemical Index of Alteration (CIA). All these parameters suggest intensive chemical weathering in the source area, which is favoured and accelerated under humid conditions in tropical to subtropical regions.

The studies carried out so far on the Jurassic paleoclimatology in Egypt are very limited. Abd El-Hameed (1997) attributed the high kaolinite content in the Middle Jurassic subsurface sediments of North Western Desert to the prevalence of warm and wet climate. In a comprehensive study on the stratigraphy of Egyptian Phanerozoic, whereas Issawi et al. (1999) mentioned that the Middle Jurassic Safa Formation was deposited under warm and rainy climatic conditions. Palynologic studies indicated that plants associated with warm and wet climates were common during Middle Jurassic times (Ali, 2000 and references therein).

Chamley (1989) suggested a latitudinal zonation of clay minerals, i.e., kaolinite, tends to concentrate towards the equator where chemical weathering is more intense. Hurst (1985) related the high kaolinite content in North Sea Jurassic sediments to the dominance of tropical and humid climates. Robert and Kennett (1994) analyzed clay mineral assemblages of the upper Paleocene sediments in the Ocean Drilling Program Sites (ODPS) and related the increased kaolinite and smectite contents with time of increased chemical weathering under temporary high temperature and rainfall. Gibson et al. (2000) indicated high abundances of kaolinite together with goethite in areas subjected to intensive chemical weathering. Aplin (1993), however, suggested that the streams draining humid regions are relatively enriched in $\mathrm{Al}$ and depleted in $\mathrm{Ca}, \mathrm{Na}$ and $\mathrm{K}$ compared to those in temperate and dry regions. He further related the high $\mathrm{Al}_{2} \mathrm{O}_{3} / \mathrm{K}_{2} \mathrm{O}$ to the high precipitation. As precipitation and chemical weathering increase, formation of kaolinite is favoured. In addition to their paleoclimatic significance, clay minerals of the Middle Jurassic succession from other locations at G. Al-Maghara will be used in the near future for further sedimentologic applications.

\section{SUMMARY AND CONCLUSIONS}

Mineralogical and chemical characteristics of Bajocian-Bathonian shales at G. Al-Maghara, North Sinai, determined in this work have been used to evaluate the climatic and depositional controls of their distribution. This succession includes the uppermost part of dominantly marine Bir Maghara Formation and the marginal marine to shallow marine Safa Formation. Mineralogical analysis carried out by XRD revealed the presence of kaolinite, smectite, and illite as the principal clay minerals, and quartz, calcite, goethite, $\mathrm{K}$-feldspars, and plagioclase as the main non-clay minerals. Kaolinite is the most abundant mineral and its abundance relative to smectite is governed by hydraulic segregation and sea-level changes. Marine shales deposited under conditions of relatively high sea level were enriched in smectite relative to kaolinite. Kaolinite is restricted to the terrigenous influx delivered to the depository during periods of sea level falls and tends to be concentrated in nearshore settings, whereas smectite is transferred to deeper marine settings due to its tiny size.

The chemical composition of the studied Bajocian-Bathonian shales reflects the enrichment of immobile elements ( $\mathrm{Al}, \mathrm{Ti}, \mathrm{Zr}$ and $\mathrm{Sc}$ ) and the depletion of many mobile elements ( $\mathrm{Ca}, \mathrm{Na}, \mathrm{K}$, $\mathrm{Fe}$ and $\mathrm{Mg}$ ). High values of CIA were recorded from most of the studied samples, especially for samples collected from the calcite-poor Safa Formation. Chemical weathering and mineralogical composition are the major factors controlling the major elemental concentrations. Trace element concentrations are influenced by the source rock chemistry, transportation effects, and chemical weathering.

The dominance of kaolinite, coupled with the enrichments of chemically immobile major elements and the high CIA values, in the BajocianBathonian shales reflects that source rock was 
subjected to strong chemical weathering, which is favoured only under tropical and subtropical humid climatic conditions. This conclusion is in agreement with the published palynofloral studies of the area.

Acknowledgments-This work is a part an ongoing Ph.D. project of the first author which is fully sponsored by the Japanese Ministry of Education, Sciences, Culture and Sports (MONBUKAGAKUSHO). We are grateful to Prof. Henning Dypvik, University of Oslo, Norway, and Dr. Shiloh Osae, Ghana Nuclear Authority, Ghana, for reviewing and improving the manuscript. We are also grateful for Prof. Christian Koeberl for reviewing and editorial comments.

\section{REFERENCES}

Abd El-Hameed, A. T. (1997) Sedimentology and geochemistry of the subsurface Jurassic Rocks in the North Western Desert, Egypt. Egyptian J. Geol. 41, 225-252.

Al-Far, D. M. (1966) Geology and coal deposits of Gebel Al Maghara North Sinai, Egypt. J. Geol. Surv. Egypt 37, 59 pp.

Ali, S. (2000) Palynostratigraphical and palaeoenvironmental studies on some subsurface Jurassic sediments, Western Desert, Egypt. M.Sc. Thesis, Tanta Univ., Tanta, Egypt, 234 pp. (in English).

Aplin, A. C. (1993) The composition of authigenic clay minerals in recent sediments: links to the supply of unstable reactants. Geochemistry of Clay-Pore Fluid Interactions (Manning, D. A. C., Hall, P. L. and Hughes, C. R., eds.), 81-106, Chapman and Hall.

Australian Rare Earth Newsletter (2001) Scandium in Australia: Resources, Applications and Links. http:/ /pandora.nla.gov.au/nph-arch/2000/H2000-Mar-1 http://www.ozemail.com.au/ marcusr/aren/ scandium.htm

Ayyad, M. H., Darwish, M. and Sehim, A. (1998) Introducing a new structural model for North Sinai with its significance to petroleum exploration. Proc. Egyptian Petroleum Corporation Exploration Seminar 14th, 1, 101-117, Egyptian Petroleum Corporation, Cairo, Egypt.

Bartov, Y., Lewy, Z. and Steinitz, G. (1980) Mesozoic and Tertiary stratigraphy, paleogeography and structural history of the Gebel Areif El Naga area. Isr. J. Earth Sci. 29, 114-139.

Bernhard, F. (2001) Scandium mineralization associated with hydrothermal lazulite-quartz veins in the Lower Austroalpine Grobgneis complex, Eastern
Alps, Austria. Mineral Deposits at the Beginning of the 21st Century. List All Editors (Piestrzynski A. and 35 others, eds.), Proc. Biennial SGA-SEG Meeting, Krakow, Poland 6th, 935-938, Balkema Rotterdam.

Brookfield, M. (1973) Paleogeography of the Upper Oxfordian and Lower Kimmeridgian (Jurassic) in Britain. Palaeogeog. Palaeoclimat. Palaeoecol. 14, 137-167.

Chamley, H. (1989) Clay Sedimentology. SpringerVerlag, Berlin, 623 pp.

Condie, C. K., Noll, P. D., Jr. and Conway, C. M. (1992) Geochemical and detrital mode evidence for two sources of Early Proterozoic sedimentary rocks from the Tonto Basin Supergroup, Central Arizona. Sedim. Geol. 77, 51-76.

Condie, K. C. (1993) Chemical composition and evolution of the upper continental crust: Contrasting results from surface samples and shales. Chem. Geol. 104, 1-37.

Cullers, R. L. (2000) The geochemistry of shales, siltstones and sandstones of Pennsylvanian-Permian age, Colorado, USA: implications for provenance and metamorphic studies. Lithos 51, 181-203.

De Wet, C. (1998) Deciphering the sedimentological expression of tectonics, eustasy, and climate: A basinwide study of the Corallian Formation, Southern England. J. Sedim. Res. 68, 653-667.

Deconinck, J.-F., Beaudoin, B., Chamley, H., Joseph P. and Raoult, J. F. (1985) Contrôles technique, eustatique et climatique do la sédimentation argileuse du domain subalpine français au Malm-Crétacé. $R e$ vue Geographie Physique et Géologie Dynamique 26, 311-320.

Dill, H., Teschner, M. and Wehner, H. (1988) Petrography, inorganic and organic geochemistry of Lower Permian carbonaceous fan sequences ("Brandschiefer Series")-Federal Republic of Germany: constraints to their paleogeography and assessment of their source rock potential. Chem. Geol. 67, 307-325.

Egyptian Geological Survey (1993) Geological map of Al-Maghara quadrangle, Sinai, Egypt. Geol. Surv. Egypt, Cairo Sheet 4, Scale: 1:100000.

Ehrenberg, S. N., Aagaard, P., Wilson, M. J., Fraser, A. R. and Duthie, D. M. L. (1993) Depth-dependent transformation of kaolinite to dickite in sandstones of the Norwegian continental shelf. Clay Minerals 28, 325-352.

El-Anbaawy, M. and Youssef, M. H. M. (1989) Recognition of diagenetic clay mineral composition in Jurassic rocks of Gebel El-Maghara area, North Sinai, Egypt. Proc. Phanerozoic Development Egypt Sympos. 5th, 35-52, Al-Azhar Univ. Cairo, Egypt.

El-Sharkawi, M. A., El-Aref, M. M. and El-Manawi, 
A. W. (1989) Paleoenvironemnts, classification and aspects of ironstones in the Mesozoic sediments of El Maghara area, North Sinai, Egypt. Egyptian Mineralogist 1, 1-25.

Füchtbauer, H. (1964) Sedimentpetrographische Untersuchungen in der älteren Molasse nördlich der Alpen. Eclogae Geol. Helv. 57, 157-298.

Garver, J. I., Royce, P. R. and Smick, T. A. (1996) Chromium and nickel in shale of the Taconic Foreland: A case study for the provenance of fine-grained sediments with an ultramafic source. J. Sedim. Res. 66, 100-106.

Ghandour, I. M. (1998) Micropaleontological and sedimentological studies on the Paleocene-Early Eocene rocks of some selected areas in Central Egypt. M.Sc. Thesis, Tanta Univ., Tanta, Egypt 128 pp. (in English).

Ghandour, I. M. (in prep.) Sequence stratigraphy, facies analysis and depositional model reconstruction of Safa Formation, G. Al-Maghara, North Sinai, Egypt. Dr.Sci. Thesis, Osaka City Univ., Japan.

Gibson, T. G., Bynell, L. M. and Mason, D. B. (2000) Stratigraphic and climatic implications of clay mineral changes around the Paleocene/Eocene boundary of the northeastern US Margin. Sedim. Geol. 134, 6592.

Gill, J. (1981) Orogenic Andesites and Plate Tectonics. Springer-Verlag, Berlin, 390 pp.

Gromet, L. P., Dymek, R. F., Haskin, L. A. and Korotev, R. L. (1984) The North American shale composite: its compilation, major and trace element characteristics. Geochim. Cosmochim. Acta 48, 2469-2482.

Guiraud, R., Issawi, B. and Bosworth, W. (2001) Phanerozoic history of Egypt and surrounding areas. PeriTethys Memoir 6: Peri-Tethyan Rift/Wrench basins and Passive Margins (Ziegler, P. A., Cavazza, W., Robertson, A. H. F. and Crasquin-Soleau, S., eds.), Mémoires du Muséum National d'Histoire Naturelle, Paris, 186, 469-509.

Hallam, A., Grose, J. A. and Ruffell, A. H. (1991) Paleoclimatic significance of changes in clay mineralogy across the Jurassic-Cretaceous boundary in England and France. Palaeogeog. Palaeoclimat. Palaeoecol. 81, 173-187.

Haq, B. U., Hardenbol, J. and Vail, P. R. (1988) Mesozoic and Cenozoic chronostratigraphy and cycles of sea-level change. Sea-Level Changes: An Integrated Approach (Wilgus, C. K., Hastings, B. S., Kendall, C. G. St. C., Posammentier, H. W., Ross, C. A. and Van Wagoner, J. C., eds.), Society of Economic Paleontologists and Mineralogists, Special Publication 42, 71-108.

Hardy, R. and Tucker, M. (1988) X-ray powder diffraction of sediments. Techniques in Sedimentology
(Tucker, M., ed.), 191-228, Blackwell Science, Cambridge.

Hegab, A. A. A. (1991) Biostratigraphic zonation of Bathonian-Callovian rocks from Gabal El Maghara, Northern Sinai, Egypt. J. African Earth Sci. 13, 183192.

Hoffman, J. and Hower, J. (1979) Clay mineral assemblages as low grade metamorphic geothermometers: application to the thrust faulted disturbed belt of Montana, USA. Aspects of Diagenesis (Scholle, P. A. and Schluger, P. S., eds.), Society of Economic Paleontologists and Mineralogists, SpecialPublication 26, 55-79.

Hurst, A. (1985) The implications of clay mineralogy to paleoclimate and provenance during the Jurassic in NE Scotland. Scotland. J. Geol. 21, 143-160.

Issawi, B., El-Hinnawi, M., Francis, M. and Mazhar, A. (1999) The Phanerozoic Geology of Egypt: A Geodynamic Approach. Geol. Surv. Egypt, Cairo, Special Publication 76, 402 pp.

Jenkins, D., Harms, J. C. and Oesleby, T. W. (1982) Mesozoic sediments of Gebel Maghara, North Sinai. Proc. Egyptian Petroleum Corporation Exploration Seminar 6th, 130-158, Egyptian Petroleum Corporation, Cairo, Egypt.

Johnson, T. C. (1996) Sedimentary processes and signals of past climatic change in the large lakes of the East African Rift Valley. The Liminology, Climatology and Paleoclimatology of the East African Lakes (Johnson, T. C. and Odada, E. O., eds.), 367-412, Gordon and Breach Publishers, Amsterdam.

Keller, W. D. (1978) Classification of kaolins exemplified by their texture in Scan Electron Micrographs. Clays and Clay Minerals 26, 161-172.

Kravchenko, S. M., Laputina, I. P., Kataeva, Z. T. and Krasilnikova, I. G. (1996) Geochemistry and Genesis of Rich Sc-REE-Y-Nb Ores at the Tomtor Deposit, Northern Siberian Platform. Geochemistry International 34, 847-863.

Lindgreen, H. and Surlyk, F. (2000) Upper PermianLower Cretaceous clay mineralogy of East Greenland: provenance, paleoclimate and volcanicity. Clay Minerals 35, 791-806.

Macquaker, J. H. S., Curtis, C. D. and Coleman, M. L. (1997) The role of iron in mudstone diagenesis: comparison of Kimmeridge Clay Formation mudstones from onshore and offshore (UKCS) localities. $J$. Sedim. Res. 67, 871-878.

Maejima, W. and Ghandour, I. M. (2002) Sedimentary facies and benthic foraminiferal biofacies of the Middle Jurassic Safa Formation, Al-Maghara, North Sinai, Egypt (Abstract). Annual Meeting Geol. Soc. Japan, 109th, pp. 262.

Manju, C. S., Narayanan Nair, V. and Lalithambika, 
M. (2001) Mineralogy, geochemistry and utilization study of the Madayi kaolin deposits, North Kerala, India. Clays and Clay Minerals 49, 355-369.

Mason, B. and Moore, C. D. (1982) Principles of Geochemistry. John Wiley \& Sons, New York, 334 pp.

Moore, D. M. and Reynolds, R. C. (1989) X-ray Diffraction and the Identification and Analysis of Clay Minerals. Oxford Univ. Press, 332 pp.

Mostafa, A. R. and Younes, M. A. (2001) Significance of organic matter in recording paleoenvironmental conditions of the Safa Formation coal sequence, Maghara area, North Sinai, Egypt. Intern. J. Coal Geol. 47, 9-21.

Moustafa, A. R. and Khalil, M. H. (1989) North Sinai structures and tectonic evolution. J. Middle East Research Centre, Ain Shams Univ. Cairo, Egypt 3, 215-231.

Nakhla, F. M. (1988) Coal in Egypt. Energy Research Centre Cairo Univ., 136 pp.

Nesbitt, H. W. and Young, G. M. (1982) Early Proterozoic climates and plate motions inferred from major elements chemistry of lutites. Nature 299, 715717.

Nyakairu, G. W. A. and Koeberl, C. (2001) Mineralogical and chemical composition and distribution of rare earth elements in clay-rich sediments from central Uganda. Geochem. J. 35, 13-28.

Pacey, N. R. (1984) Bentonites in the Chalk of central eastern England and their relation to the opening of the northeast Atlantic. Earth Planet. Sci. Lett. 67, 4860.

Perry, E. A. and Hower, J. (1970) Burial diagenesis in Gulf Coast politic sediments. Clays and Clay Minerals 18, 165-177

Petschik, R., Kuhn, G. and Gingele, F. (1996) Clay mineral distribution in surface sediments of the South Atlantic: sources, transport and relation to oceanography. Mar. Geol. 130, 203-229.

Quinby-Hunt, M. S., Wilde, P. and Berry, W. B. N. (1991) The provenance of low-calcic black shales. Mineralium Deposita 26, 113-121.

Raucsik, B and Merényi L. (2000) Origin and environmental significance of clay minerals in the Lower Jurassic formations of the Mecsek Mts., Hungary. Acta Geol. Hungarica 43, 405-429.

Robert, C. and Kennett, J. P. (1994) Antarctic subtropical humid episode at the Paleocene-Eocene boundary: clay mineral evidence. Geology 22, 211-214.

Rollinson, H. (1993) Using Geochemical Data: Evaluation, Presentation, Interpretation. Longman Scientific and Technical, New York, 352 pp.

Ronov, A. B. and Migdisov, A. A. (1971) Geochemical history of the crystalline basement and the sedimen- tary cover of the Russian and North American platforms. Sedimentology 16, 137-185.

Ruffel, A. H. and Rawson, P. F. (1994) Paleoclimate control on sequence stratigraphic patterns in the Late Jurassic to Mid-Cretaceous, with a case study from eastern England: Palaeogeog. Palaeoclimat. Palaeoecol. 110, 43-54.

Schroeder, P. A. and Shiflet, J. (2000) Ti-bearing phases in the Huber Formation: an east Georgia kaolin deposit. Clays and Clay Minerals 48, 151-158.

Schultz, L. G., Tourtelot, H. A., Gill, J. R. and Boerngen, J. G. (1980) Composition and Properties of the Pierre Shale and Equivalent Rocks, Northern Great Plains Region. Geochemistry of the Pierre Shale and Equivalent Rocks of late Cretaceous age. U.S. Geological Survey Professional Paper, 1064B, 114 pp.

Shahin, A. (2000) Contribution to the Bathonian benthic foraminifera and ostracoda and their paleoenvironments in Gebel El Maghara, northern Sinai, Egypt. Bull Faculty Science, Mansoura Univ. Mansoura, Egypt. 27, 25-62.

Singer, A. (1984) The paleoclimatic interpretation of clay minerals in sediments: A review. Earth Sci. Rev. 21, 251-293.

Speijer, R. P. (1994) Extinction and recovery patterns in benthic foraminiferal paleocommunities across the Cretaceous/Paleogene and Paleocene/Eocene boundaries. Ph.D Thesis, Utrecht Univ., 124 pp. (in English).

Stow, D. A. V. and Atkin, B. P. (1987) Sediment facies and geochemistry of Upper Jurassic mudrocks in the central North Sea area. Petroleum Geology of North West Europe (Brooks J. and Glennie K., eds.), 797808, Graham and Trotman, London.

Taylor, S. R. and McLennan, S. M. (1985) The Continental Crust: Its Composition and Evolution. Blackwell, London, 312 pp.

Van Wagoner, J. C., Mitchum, R. M., Campion, K. M. and Rahmanian, V. D. (1990) Siliciclastic sequence stratigraphy in Well Logs, Cores and Outcrops: Concepts for high-resolution correlation of time and facies. American Association Petroleum Geologists Methods Exploration Series 7, 55 pp.

Visser, J. N. J. and Young, G. M. (1990) Major element geochemistry and Paleoclimatology of the PermoCarboniferous glacigene Dwyka Formation and postglacial mudrocks in Southern Africa. Palaeogeo. Palaeoclimat. Palaeoecol. 81, 49-57.

Vital, H., Stattegger, K. and Garbe-Schonberg, C. (1999) Composition and trace element geochemistry of detrital clay and heavy-mineral suites of the lowermost Amazon River: a provenance study. $J$. Sedim Res. 69, 563-575. 
Wronkiewicz, D. J. and Condie, K. C. (1987) Geochemistry of Archean shales from the Witwaltersrand Supergroup, South Africa: Source area weathering and provenance. Geochim. Cosmochim. Acta 51, 2401-2416.
Young, G. M. and Nesbitt, H. W. (1998) Processes controlling the distribution of $\mathrm{Ti}$ and $\mathrm{Al}$ in weathering profiles, siliciclastic sediments and sedimentary rocks. J. Sedim. Res. 68, 448-455. 